Portland State University

PDXScholar

$5-24-2019$

\title{
Literature Review on the Effects of Water Fluoridation on the Human Health
}

Diana Abdeljawad

Portland State University

Follow this and additional works at: https://pdxscholar.library.pdx.edu/honorstheses Let us know how access to this document benefits you.

\section{Recommended Citation}

Abdeljawad, Diana, "Literature Review on the Effects of Water Fluoridation on the Human Health" (2019). University Honors Theses. Paper 708.

https://doi.org/10.15760/honors.725

This Thesis is brought to you for free and open access. It has been accepted for inclusion in University Honors Theses by an authorized administrator of PDXScholar. Please contact us if we can make this document more accessible: pdxscholar@pdx.edu. 
Literature Review on the Effects of Water Fluoridation on the Human Health

by

\begin{abstract}
Diana Abdeljawad
An undergraduate honors thesis submitted in partial fulfillment of the requirements for the degree of

Bachelor of Science

in

University Honors

and

Science/Chemistry
\end{abstract}

Thesis Adviser

Bradley Buckley, PhD

Portland State University

2019 
LITERATURE REVIEW ON THE EFFECTS OF WATER FLUORIDATION ON THE

$\begin{array}{ll}\text { HUMAN HEALTH } & 2\end{array}$

Table of Contents

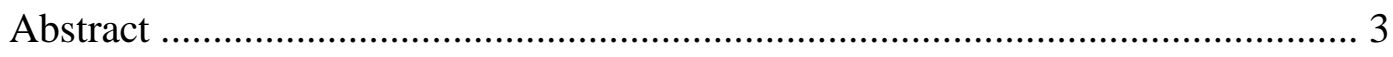

Background information....................................................................... 4-6

Fluoride................................................................................. 4

Fluoride toothpaste.................................................................. 5

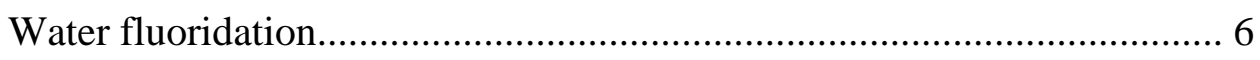

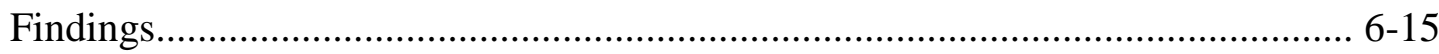

Dental Fluorosis........................................................................... $6-8$

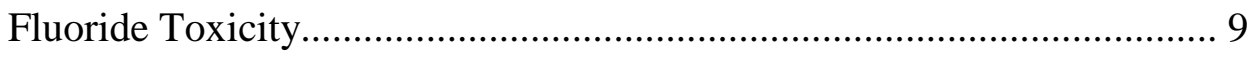

Fluoride Effect on Pineal Gland......................................................... 10

Fluoride Effect on Other Organs...................................................... 10 10 11

Fluoride Experiments.............................................................. 11-12

Water Fluoridation Distribution......................................................... 13-16

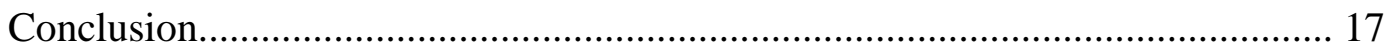

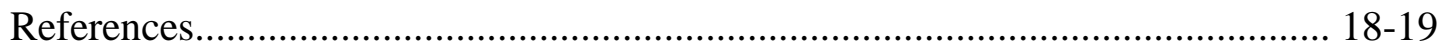




\title{
LITERATURE REVIEW ON THE EFFECTS OF WATER FLUORIDATION ON THE
}

\begin{abstract}
This thesis is a literature review of water fluoridation on the human health. As it compares many different articles about the advantages and disadvantages of having fluoride in water, and its effects on health. The thesis dives into many key points that supports the idea of fluoridated water. Such as a background information of what fluoride is, fluoride in different components like toothpaste, a general idea of what water fluoridation is, and findings that were found during the literature review. The findings include dental fluorosis, fluoride toxicity, fluoride's effect on the pineal gland and other organs, experiments conducted via fluoride, and the distribution of fluoridated water across the United States.

Water fluoridation has been one of the greatest debates many of the states in the US are facing. Which is due to the consistent fluctuation of the amount of fluoride in waters of many cities in the US. Where some cities within the states stopped water fluoridation, some decreased the amount of fluoride in their water, and some kept it as it is. There are many benefits towards fluoridated water that includes oral health. However, there are also many disadvantages of fluoridated water, it can affect parts of the brain and the organs of the body in negative ways.

By examining both the advantages and the disadvantages of having fluoridated water and comparing two similar states' oral health and overall body health, through literature reviews, I have concluded that water fluoridation at a small amount is beneficial and should be set to an optimal level of $0.7 \mathrm{mg}$ of fluoride for every liter of water.
\end{abstract}

Keywords: Fluoride, fluoridation, water, effects. 


\section{LITERATURE REVIEW ON THE EFFECTS OF WATER FLUORIDATION ON THE}

$\begin{array}{ll}\text { HUMAN HEALTH } & 4\end{array}$

\section{Effects of Water Fluoridation}

Water fluoridation has many effects. Here I will distinguish between the positive and negative effects of water fluoridation, but first I will describe each term in details. After that I will be showing evidence on the outcome of fluoridation. By the end of this I would want to make it clear on whether water fluoridation is beneficial or not and whether or not it should be distributed around the US.

\section{Background}

\section{Fluoride}

Fluoride is well known to be one of main the elements within the periodic table. "Fluorine is the world's 13 th most abundant element and constitutes $0.08 \%$ of the Earth crust. It has the highest electronegativity of all elements. Fluoride is widely distributed in the environment, occurring in the air, soils, rocks, and water. Although fluoride is used industrially in a fluorine compound, the manufacture of ceramics, pesticides, aerosol propellants, refrigerants, glassware..." (Peckham and Awofeso, 2014)

The first thing most people will think of when thinking about fluoride would be toothpaste. As mostly all toothpastes have fluoride within them. However, that is not the only thing that contains fluoride, the water we drink also contains fluoride. One of the biggest controversy that is happening is water fluoridation and whether it is beneficial or not. 


\section{LITERATURE REVIEW ON THE EFFECTS OF WATER FLUORIDATION ON THE}

HUMAN HEALTH

\section{Fluoride Toothpaste}

Historical findings, "After concluding 21 -city study $(25,26)$, historians found that drinking water with 1 ppm of fluoride can prevent dental caries, increase tooth strength and does not have a negative impact on enamel." (Kanduti et al., 2016) This is due to how fluoride works with hydroxyapatite. "Hydroxyapatite I is the main mineral responsible for building the permanent tooth enamel after the development of the teeth is finished" (Kanduti et al., 2016)

Fluoride keeps hydroxyapatite $\mathrm{pH}$ level stable. "When the $\mathrm{pH}$ falls below the critical level of hydroxyapatite ( $\mathrm{pH} 5.5$ ), the process of demineralization of enamel takes place and caries is formed..... When the $\mathrm{pH}$ rises above the critical level of 5.5, the increased level of fluoride ion leads to remineralization, because it absorbs itself into the enamel and forms fluorhydroxyapatite" (Kanduti et al., 2016)

According to NBC News toothpastes without fluoride does not protect the enamel or the oral health. " "It's really important to debunk this idea that brushing your teeth stops decay. You need to have the fluoride," said Damien Walmsley, a scientific adviser to the British Dental Association and a dentistry professor at the University of Birmingham in England." However ingesting toothpaste that contains fluoride may lead to several side effects, including fluorosis. Water that contains fluoride can "reduces tooth decay by 20 to 40 percent" (Nordqvist, 2018) 


\section{LITERATURE REVIEW ON THE EFFECTS OF WATER FLUORIDATION ON THE}

\section{Water Fluoridation}

Water fluoridation has its benefits and it also has its downside. The benefits of having fluoride in water is oral health. According to the American Dental Association, "Adding fluoride is like fortifying milk with vitamin D, orange juice with calcium, or cereals with B vitamins and folic acid." (Nordqvist, 2018) This is because "Tooth decay is one of the most common health problems affecting children. Many people worldwide cannot afford the cost of regular dental checks, so adding fluoride can offer savings and benefits to those who need them." (Nordqvist, 2018).

\section{Findings}

The findings for water fluoridation was that it had many negative impact on the overall body's health of humans and even animals. One of the main issues back in the days was fluoride toxicity, nowadays it is dental fluorosis. Studies shown that fluoridated water has some physiological effects. It also may be toxic and impact the pineal gland and other organs in the body. Based on the research, the only positive effect of fluoride came within toothpastes.

\section{Dental Fluorosis}

"Dental fluorosis is a developmental disturbance of enamel which occurs during enamel forming."(Kanduti et al., 2016) In other words, it is a disorder of teeth formation. This can be seen as white patches on the tooth, which indicates dental fluorosis. Studies showed that the main reason of dental fluorosis is ingesting fluoride through water or food, like fish. Since fish 


\section{LITERATURE REVIEW ON THE EFFECTS OF WATER FLUORIDATION ON THE}

HUMAN HEALTH

are aquatic species their environment is at huge risk of containing fluoride "the amount of fluoride present in fishes is directly related to the amount of Fluoride in the habitat they live in."

(Ganta et al., 2015) Thus, when consuming these fish a person would also be consuming a small quantity of fluoride. "Recent studies reported average fluoride values for fish close to 0.05 $\mathrm{mg} / 100 \mathrm{~g}$ and a range of 0.01 to $0.17 \mathrm{mg} / 100 \mathrm{~g}$." (Ganta et al., 2015) Consuming a large amount of these fish would result to dental fluorosis.

"Most of the ingested fluorides reach the teeth via saliva, whose fluoride content varies from less than 0.01 to $0.05 \mathrm{ppm}$. Fluoride absorption in bones and teeth decreases with increasing age" (Peckham and Awofeso, 2014) Since dental fluorosis occurs during tooth development, the younger the person is the more likely they would develop dental fluorosis. In this case, children are affected the most.

An analysis was created based on a total of 88 dental fluorosis studies. "Each circle represents a study area in which the proportion of people with fluorosis is estimated - the larger the circle, the higher the precision of the estimate"(McDonagh et al., 2000) These are indicated in Figures 1 and 2. 


\section{LITERATURE REVIEW ON THE EFFECTS OF WATER FLUORIDATION ON THE}

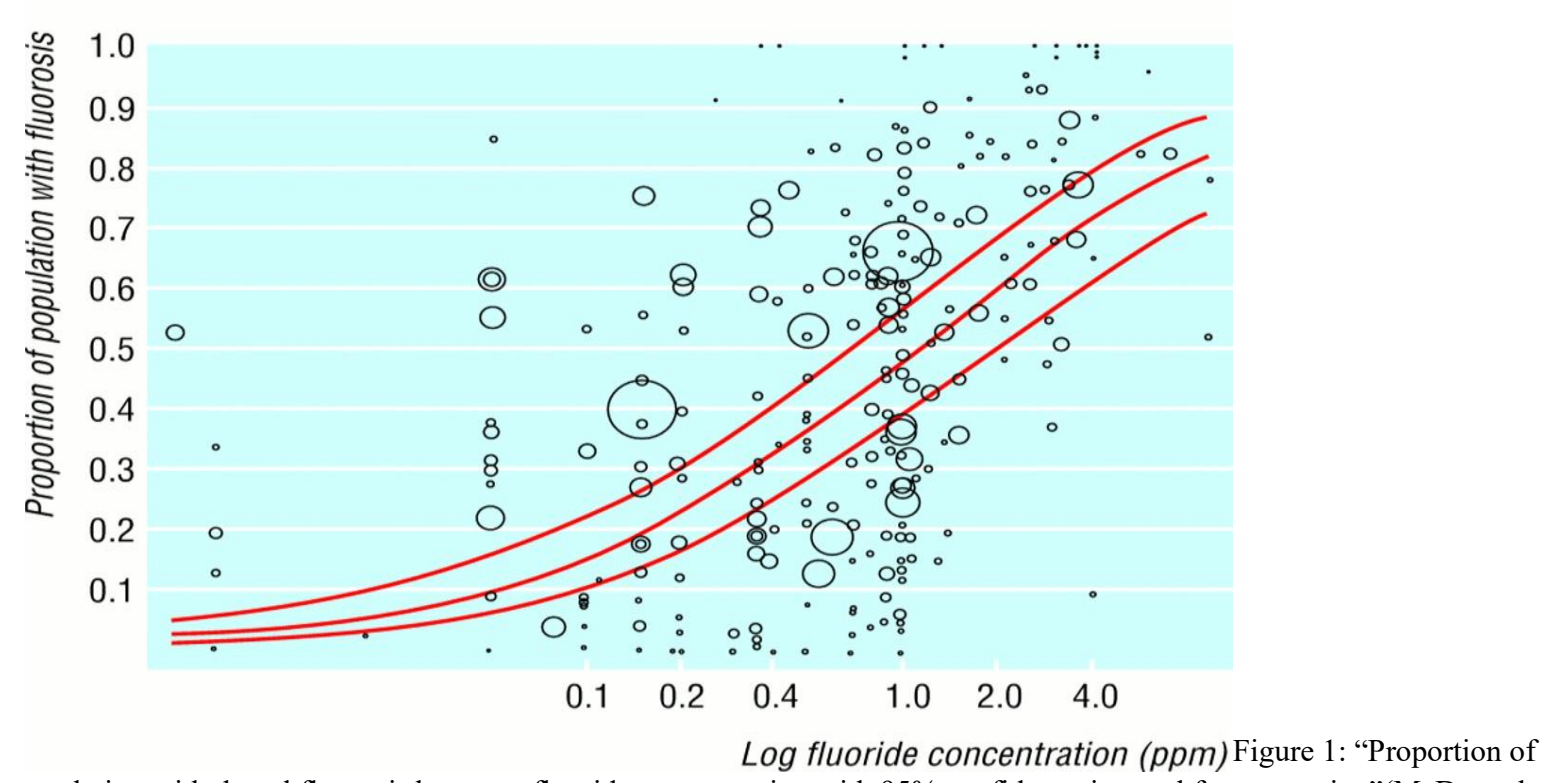

population with dental fluorosis by water fluoride concentration with $95 \%$ confidence interval for proportion"(McDonagh et al., 2000)

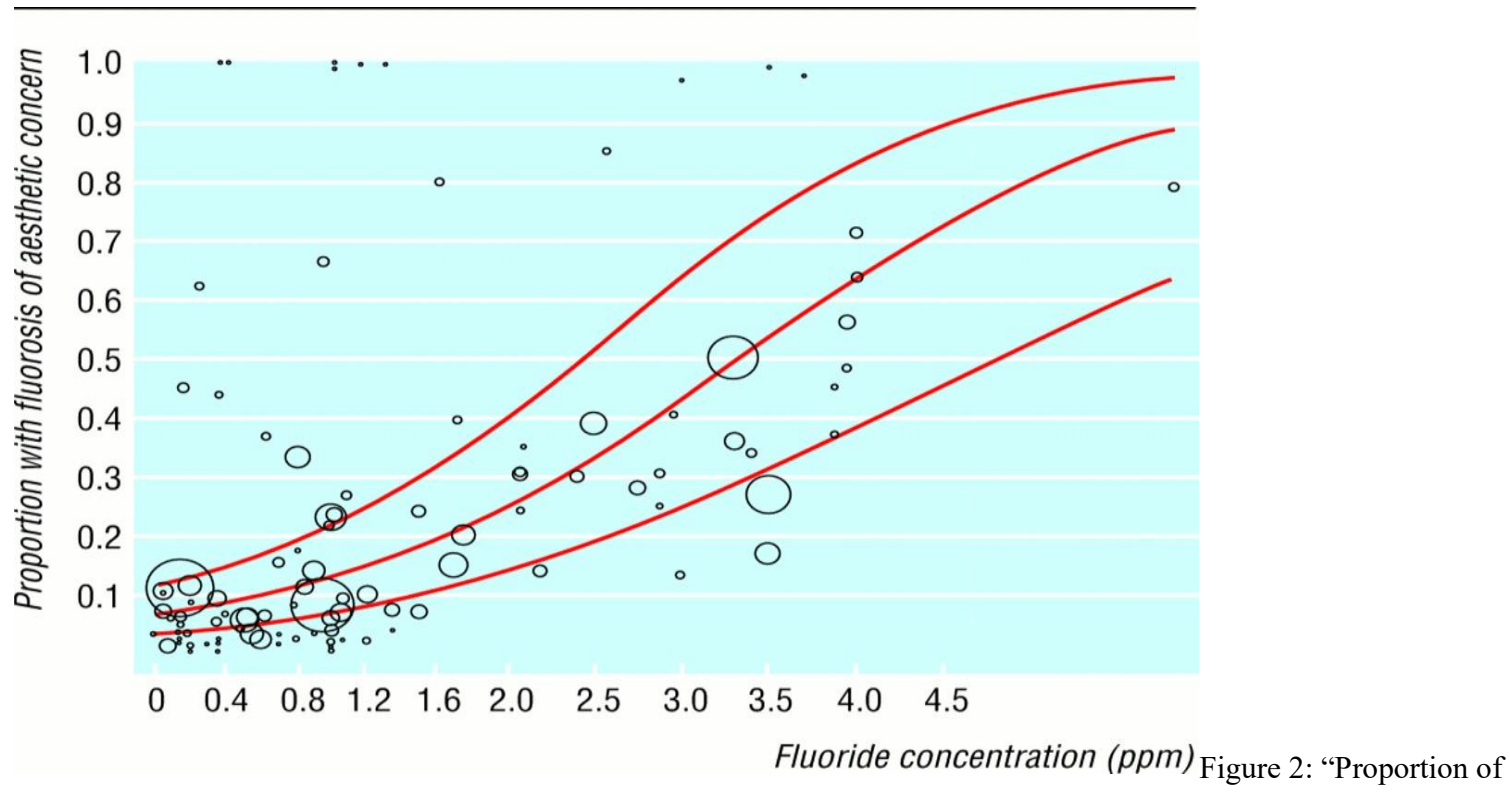

population with fluorosis of aesthetic concern by water fluoride concentration”(McDonagh et al., 2000)

"These results show a strong association between water fluoride concentration and the proportion of the population with dental fluorosis.... The prevalence of fluorosis (mottled teeth) is highly associated with the concentration of fluoride in drinking water"(McDonagh et al., 2000) Fluoride Toxicity 


\section{LITERATURE REVIEW ON THE EFFECTS OF WATER FLUORIDATION ON THE}

HUMAN HEALTH

"Acute toxicity can occur after ingesting one or more doses of fluoride over a short time period which then leads to poisoning. The stomach is the first organ that is affected." (Kanduti et al., 2016) When the stomach is affected, this would lead to problems occuring in the intestines which would cause stomach and bowel disorders.

Back in the days sodium fluoride (Figure 3) was mistaken as powdered milk (Figure 4), since it has the same white powder texture "The most notable example is from the Oregon State Hospital from 1942. During the preparation of scrambled eggs powdered milk was replaced by sodium fluoride which caused 467 cases of acute poisoning of which 47 were fatal. This incident is considered to be the largest mass fluoride poisoning." (Kanduti et al., 2016)

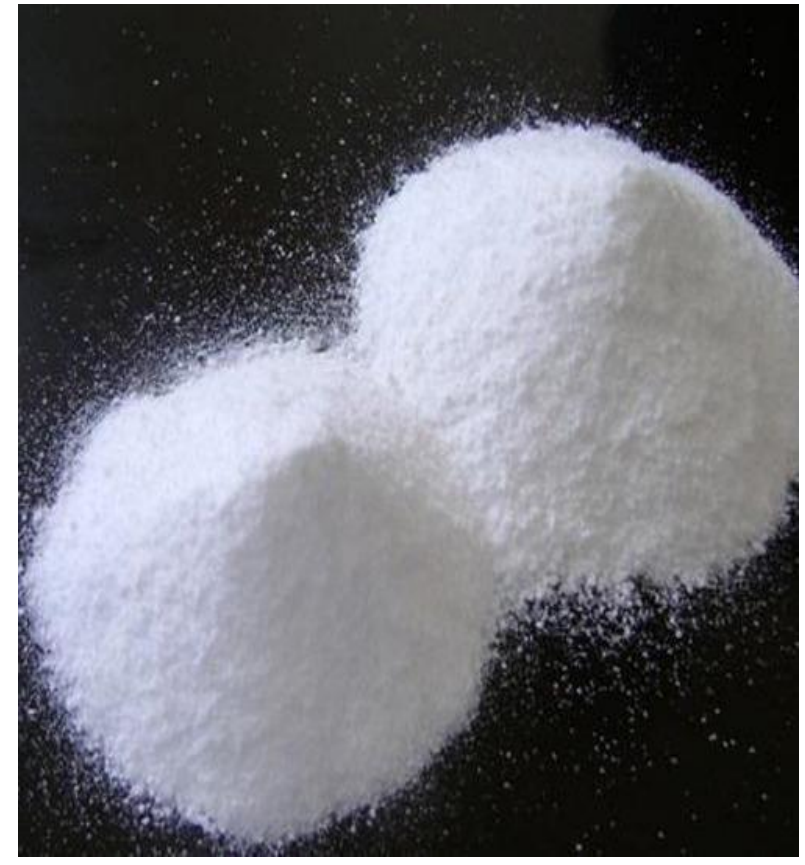

Figure 3: Sodium Fluoride. (archived via google images)

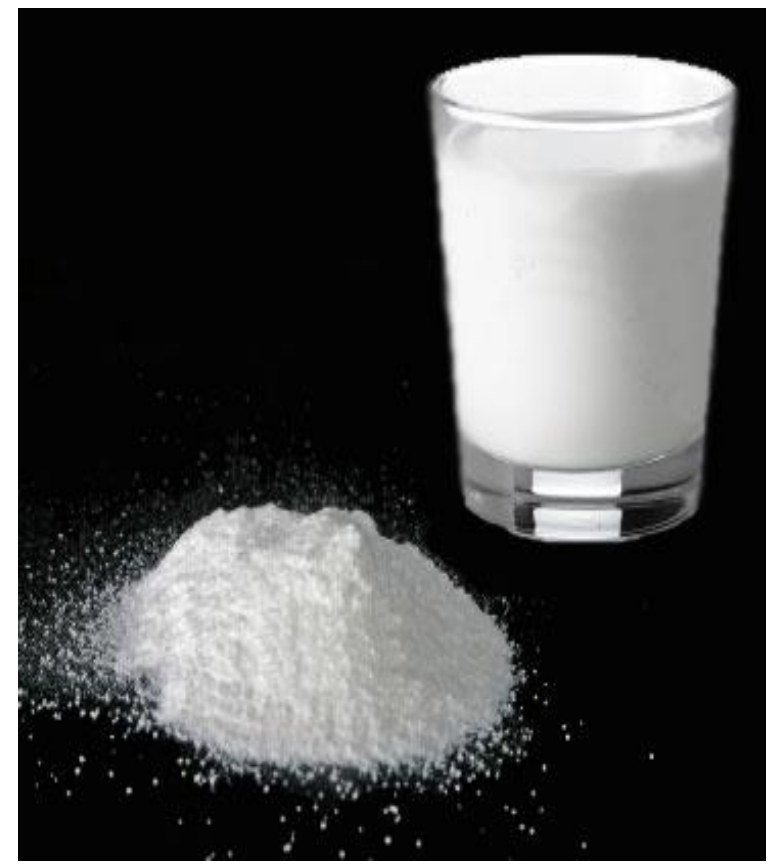

Figure 4: Powdered milk. (archived via google images) 


\section{LITERATURE REVIEW ON THE EFFECTS OF WATER FLUORIDATION ON THE}

HUMAN HEALTH

The pineal gland is a gland within a brain. "Located in the center of the brain, it's responsible for melatonin synthesis (which plays a role in maintaining normal rhythms and sleep cycles), and also helps convert signals between our nervous and endocrine systems.”(Dr.

Edward, 2015) Many studies has shown that the pineal gland can be negatively affected by fluoride consumption.

"The pineal gland is a mineralizing tissue. Its calcified concretions range from a few micrometres to several millimetres in diameter."(Luke, 2001) "Fluoride can accumulate and calcify on the gland, blocking its effectiveness, and these deposits can get worse as we age. A blocked pineal gland could lead to things like trouble sleeping or weight gain." (Dr. Edward, 2015)

\section{Fluoride Effect on Other Organs}

When fluoride enters the body, "About $90 \%$ of fluoride is absorbed in the gastrointestinal tract after consumption (up to $25 \%$ in the stomach and around $77 \%$ in proximal part of the small intestine). The remaining $10 \%$ is excreted in feces" (Kanduti et al., 2016). The only organ that can maintain fluoride concentration in the body are the kidneys. Which means, a person with one kidney would have a harder time to maintain fluoride concentrations, if highly ingested.

"Prolonged ingestion of fluoride adversely affects the teeth, bones and other organs and alters their anatomy and physiology.’(Kurdi, 2016)

Fluoride ingestion can also have negative impacts on the skeletal system, bones, in the body. "Excess exposure to fluoride can lead to a bone disease known as skeletal fluorosis." (Nordqvist, 2018) Skeletal fluorosis is a condition where the bones in the body weakens, hardens 


\section{LITERATURE REVIEW ON THE EFFECTS OF WATER FLUORIDATION ON THE}

HUMAN HEALTH

and becomes less elastic, thus causing the bone to easily fracture. A study was created to assess the influence of fluoride, or sodium fluoride, towards the process of bone formation. " It was concluded that sodium fluoride not only increases osteoblast activity but also stimulates bone resorption in bone matrix grafts.” (Toxicity Effect, n.p)

Another feature in the body fluoride effects is the parathyroid gland where, "excess fluoride can damage the parathyroid gland. This can result in hyperparathyroidism, which involves uncontrolled secretion of parathyroid hormones." (Nordqvist, 2018) which, the parathyroid hormone, secretes calcium in the blood. Excess amount of calcium in the blood causes pain in the abdominal, bones, and muscles.

\section{Fluoride experiments}

According to the American Hospital Formulary Service (AHFS) the amount of fluoride that is fatal is around 5-10g for adults and 500mg for children. (Toxicity Effect, n.p) Based on these amounts many different experiments were conducted to prove whether water fluoridation is an issue.

To determine whether fluoride ingestion could affect the internal human body an experiment was conducted with volunteers, patients. "The patients were treated with fluoridecontaining formulations (disodium monofluorophosphate and sodium fluoride) for a period of 15 months up to 49 months. Fluoride intake ranged from 22.6 to $33.9 \mathrm{mg}$ F/day and serum fluoride concentrations were between $0.1 \mathrm{mg} \mathrm{F} / \mathrm{L}$ and $0.2 \mathrm{mg} \mathrm{F} / \mathrm{L} . "$ (Toxicity Effect, n.p) The result of these tests were negative, as there was no genotoxic potential from fluoride to the human body. 


\section{LITERATURE REVIEW ON THE EFFECTS OF WATER FLUORIDATION ON THE}

HUMAN HEALTH

Some experiments were made via rats and frogs, as frogs and rats have similar anatomy to humans. The rat experiment was done to see fluorides effects on teeth and gums, and the results were, "that/ fluoride supplementation causes changes in the developmental pattern of DSP expression and its distribution in rat tooth germs."(Toxicity Effect, n.p) DSP is a gene that creates a protein called desmoplakin, which is found in heart and skin cells. The other experiment was on frogs, which was conducted to detect whether a large amount of fluoride ingestion would cause birth defects. The results were that the ".... action of sodium fluoride on frog embryos would indicate a strong possibility that sodium fluoride may also act directly on developing mammalian fetuses to cause malformation" (Toxicity Effect, n.p)

Another experiment was conducted by scientists, on the effect of the amount of sodium fluoride in drinking water within a 6 month period. The amounts varied between $10-50 \mathrm{mg} / \mathrm{L}$ NaF. "The present results revealed that prolonged ingestion of fluoride through drinking water, particularly with high doses, induced significant histopathological and biochemical changes leading to myocardial tissue damage.’(Toxicity Effect, n.p) In other words, it affected and damaged the heart. As long as fluoride stays within a specific range within water there would be no negative side effects. "The Department of Health and Human Services (DHHS) sets the optimal level of fluoride for preventing tooth decay at $0.7 \mathrm{ppm}$, or 0.7 milligrams $(\mathrm{mg})$ in every liter of water." (Nordqvist, 2018)

\section{Water fluoridation distribution}

There are around 25 countries, over 200 million people, have high fluoride levels in their ground water. The high fluoridation in their waters cause millions of people at health risks. 


\section{LITERATURE REVIEW ON THE EFFECTS OF WATER FLUORIDATION ON THE}

HUMAN HEALTH

(Ganta et al., 2015) Most of the health risks involve children since they retain higher levels of fluoride than adults. "Adults retain around $36 \%$ of fluoride, whereas children retain approximately 50\% of fluoride.”(Kanduti et al., 2016) Water fluoridation is affecting many people across the world, particularly the US. Many cities within each state decided to decrease the amount of fluoride in their water.

Some cities like Portland, Oregon eliminated water fluoridation. In fact, Portland is the largest city in the US that has stopped water fluoridation. Figure 3 shows that Oregon as an entire state is one of the states that contain the least amount of fluoride in their waters compared to the rest of the states. Hawaii has the lowest percent of water fluoridation, New Jersey is second, and Oregon has the third lowest. Washington D.C, however, has the highest water fluoridation at 100\% (Figure 5). 


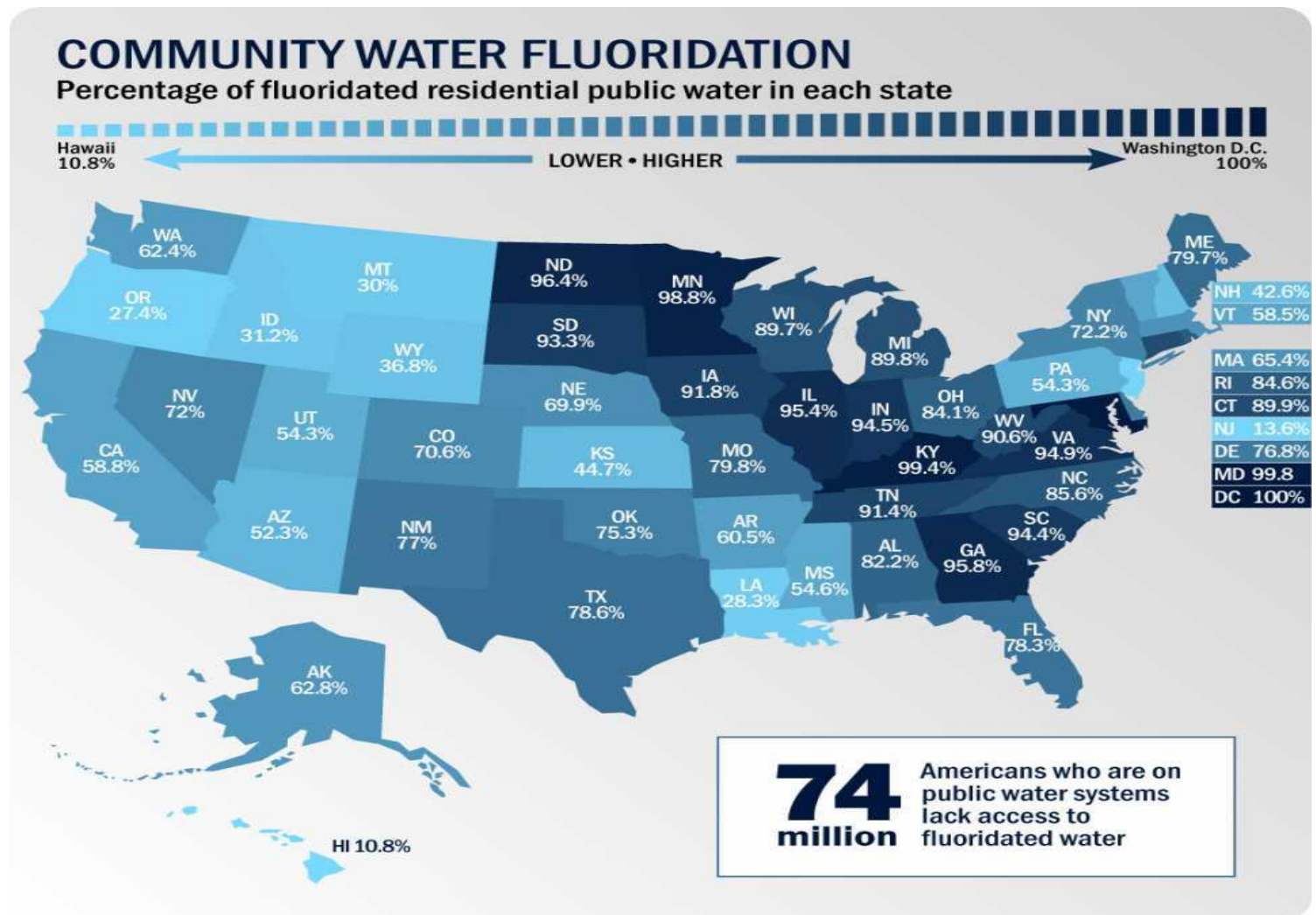

Figure 5: Water fluoridation around the USA. (archived via google images; Aquasana inc.)

Many important groups are supporting water fluoridation. "Those who support water fluoridation - a group that includes the Centers for Disease Control and Prevention, the American Academy of Pediatrics and the American Dental Association" (Oster, 2014) As a matter of fact, California held the largest city in the US without water fluoridation until 2014 where it added fluoride to their water causing Portland to come in as the first largest city. This was due to the major groups supporting fluoridated water.

As seen in Figure 5, Oregon is at $27.4 \%$ fluoridated water while Washington is at $62.4 \%$. Also, according to the American Dental Association Oregon and Washington states are in the top 20 best dental care in the US. A comparison between Oregon and Washington states, since the eating habits of the population within these two states are quite the same, is seen in Table 1 and 
LITERATURE REVIEW ON THE EFFECTS OF WATER FLUORIDATION ON THE

HUMAN HEALTH

Figures $6 \& 7$ to determine whether water fluoridation impact teeth or not.

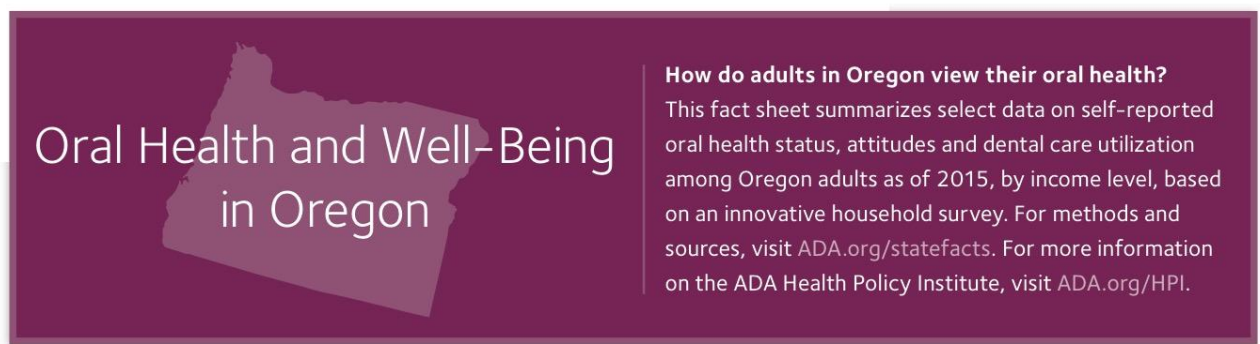

Overall Condition of Mouth and Teeth
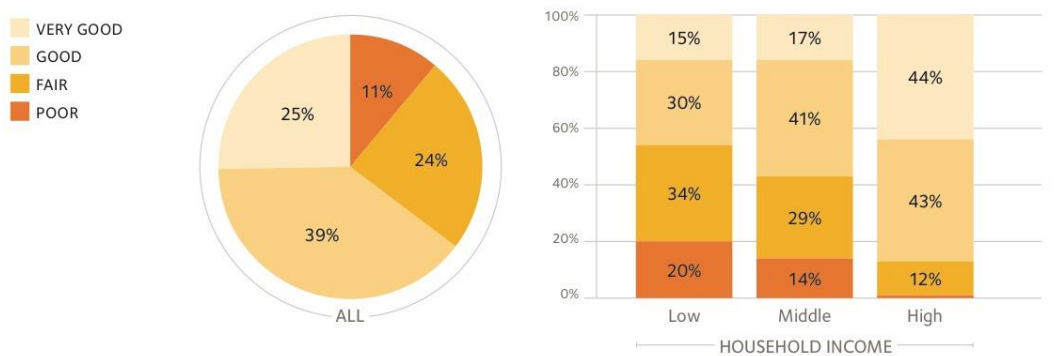

Figure 6: Oregon's overall oral health condition. Retrieved from the ADA website.

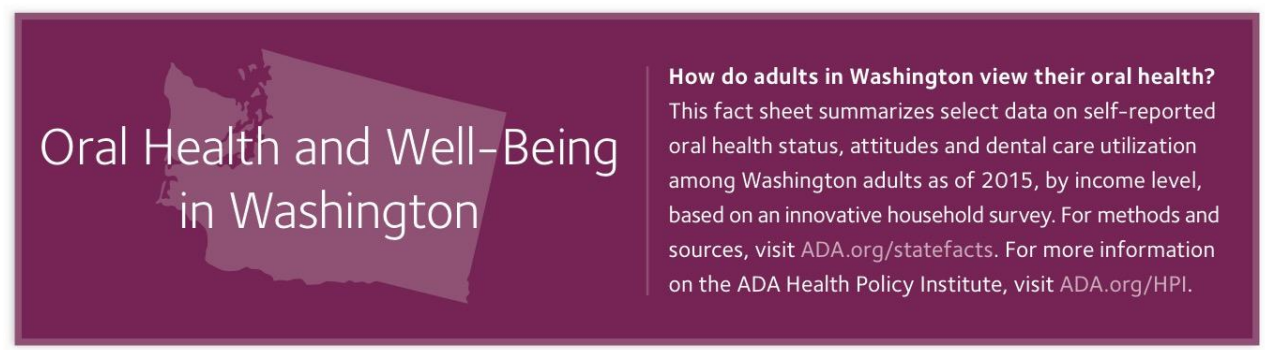

Overall Condition of Mouth and Teeth

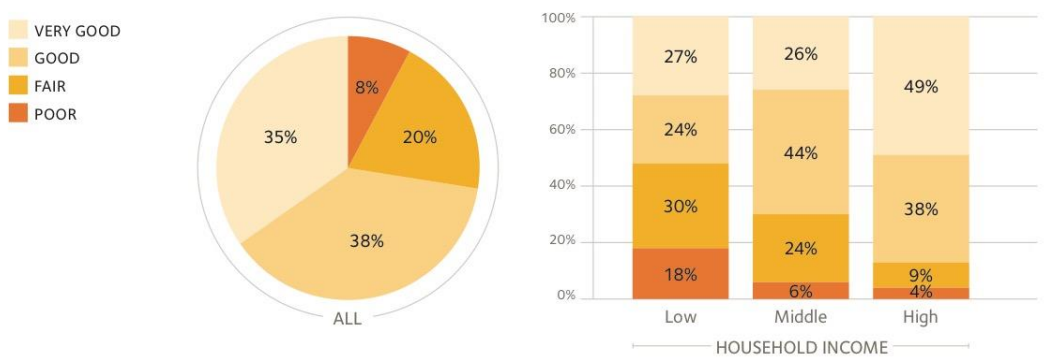

Figure 7: Washington's overall oral health condition. Retrieved from the ADA website. 


\section{LITERATURE REVIEW ON THE EFFECTS OF WATER FLUORIDATION ON THE}

HUMAN HEALTH

According to the two figures above (Figures 4 and 5) Washington state's population have better overall mouth and teeth condition compared to Oregon. As Washington state has an average of good + very good overall oral condition of $73 \%$ (Figure 7) and Oregon is at $64 \%$ (Figure 6). Despite the difference, the two states have very similar oral health outcomes. Even though Oregon and Washington have different amounts of water fluoridation they both have strong dental care, which is a huge factor in regards to oral health.

\section{Every state ranked by healthiness, 2018}

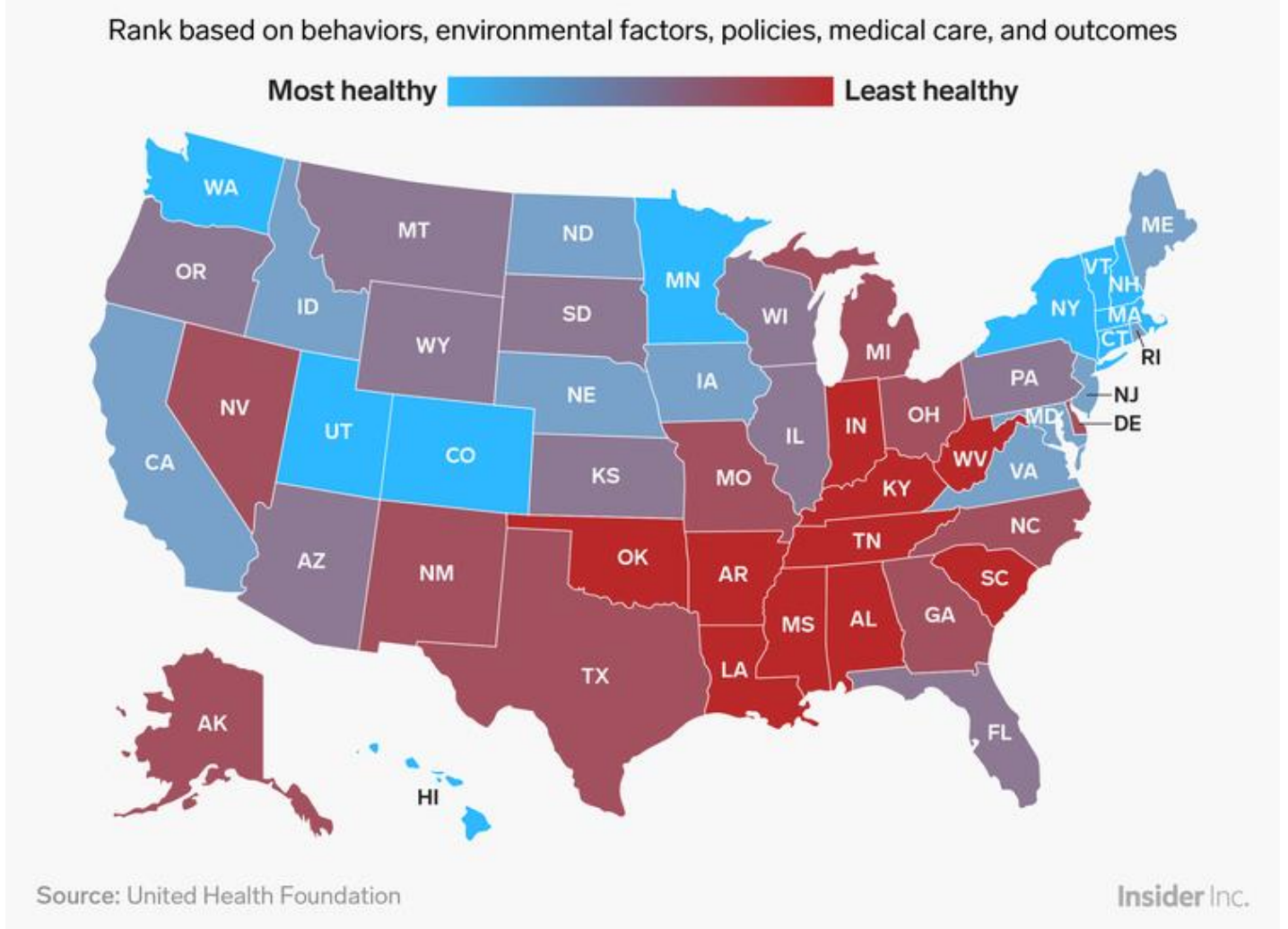

Figure 8: Healthiness of each state in the US. Retrieved from United Health Foundation.

Washington state is one of the healthiest state in the US, and Oregon is one of the states that are leaning towards the unhealthiest (Figure 8). Healthcare in both states are similar, however as seen in Figure 8 their population's health differ. 


\section{LITERATURE REVIEW ON THE EFFECTS OF WATER FLUORIDATION ON THE}

$\begin{array}{ll}\text { HUMAN HEALTH } & 17\end{array}$

\section{Conclusion}

Fluoride has its negative and positive impact towards the body when using or consuming it. It is healthy in the form of toothpaste and small amounts in water, as it protects one's oral mouth especially teeth. Fluoride's negative effect comes in higher concentrations within water. As water fluoridation has become one of the largest challenges public health is facing, as many negative impacts had emerged. Such as dental fluorosis, skeletal fluorosis, effects on the pineal gland, stomach, gastrointestinal tract, and the parathyroid gland.

With the findings found in this literature review of water fluoridation, a small amount of fluoride would not impact the human health however a large amount will. Looking back at the comparison made between water fluoridation in Oregon and Washington and the healthiness of each state's population a conclusion can be drawn. Water fluoridation in both states differed significantly however they both had similar oral health care due to the fact that they both have great dental care, but when looking at the overall healthiness of the two states it was clear that Washington state's population are healthier than Oregon. Therefore, water fluoridation has a great impact on the overall body's health and as long as it is within the optimal level of about $0.7 \mathrm{mg}$ of fluoride per liter of water there would not be any health risks. 


\section{LITERATURE REVIEW ON THE EFFECTS OF WATER FLUORIDATION ON THE}

$\begin{array}{ll}\text { HUMAN HEALTH } & 18\end{array}$

\section{References}

Ganta, S., Yousuf, A., Nagaraj, A., Pareek, S., Sidiq, M., Singh, K., \& Vishnani, P. (2015). Evaluation of Fluoride Retention Due to Most Commonly Consumed Estuarine Fishes Among Fish Consuming Population of Andhra Pradesh as a Contributing Factor to Dental Fluorosis: A Cross-Sectional Study. Journal of clinical and diagnostic research : JCDR, 9(6), ZC11-5

Kanduti, D., Sterbenk, P., \& Artnik, B. (2016). FLUORIDE: A REVIEW OF USE AND EFFECTS ON HEALTH. Materia socio-medica, 28(2), 133-7.

Kurdi M. S. (2016). Chronic fluorosis: The disease and its anaesthetic implications. Indian journal of anaesthesia, 60(3), 157-62.

Luke, J. (2001). Fluoride Deposition in the Aged Human Pineal Gland. School of Biological Sciences, University of Surrey, Guildford, UK. Department of Obstetrics and Gynaecology, The Royal London Hospital. Caries Res 2991;35:125-128

McDonagh, M. S., Whiting, P. F., Wilson, P. M., Sutton, A. J., Chestnutt, I., Cooper, J., . . Kleijnen, J. (2000, October 07). Systematic review of water fluoridation. BMJ 2000;321:855.

Nordqvist, C. (2018, February 21). Why do we have fluoride in our water? Medical News Today. Retrieved from https://www.medicalnewstoday.com/articles/154164.php

Oster, E. (2014, November 10). Are The Concerns About Water Fluoridation Legit? Dental Health. ABC News. Retrieved from

Peckham, S., \& Awofeso, N. (2014). Water fluoridation: a critical review of the physiological effects of ingested fluoride as a public health intervention. TheScientificWorldJournal, 2014, 2.

Wright, J. T., Hanson, N., Ristic, H., Whall, C. W., Estrich, C. G., \& Zentz, R. R. (2014). Fluoride toothpaste efficacy and safety in children younger than 6 years. The Journal of the American Dental Association, 145(2), 182-189. doi:10.14219/jada.2013.37 


\section{LITERATURE REVIEW ON THE EFFECTS OF WATER FLUORIDATION ON THE}

Edward, Dr. (2015, November 16). How Fluoride Damages Pineal Gland Health. Global Health Center.

Experts question benefits of fluoride-free toothpaste. Associated Press. NBC News. (2018, August 7). Retrieved from https://www.nbcnews.com/health/health-news/experts-questionbenefits-fluoride-free-toothpaste-n898311

Toxicity Effects. (n.d.). Retrieved from https://tools.niehs.nih.gov/cebs3/ntpviews/index.cfm?action=testarticle.toxicity\&cas_number=76 $81-49-4$ https://tools.niehs.nih.gov/cebs3/ntpviews/index.cfm?action=testarticle.toxicity\&cas_number=76 81-49-4 